УДК: $7.033 .4 . .21 ; 7.027 .2$

ББК: $85.126 ; 66.1(0)$

DOI:10.18688/aa155-4-40

Allan George Doig

\title{
Building, Enacting and Embodying Romanitas: the Throne of Charlemagne
}

Romanitas is a difficult term to pin down. In this context it seems reasonable to take it in the broad sense of the inheritance of Rome being consciously recalled and used ideologically to reinforce a particular authority. In that sense romanitas and auctoritas are closely related, with both concepts projecting permanence, stability and order. In the search for these attributes, those at the pinnacle of political power have historically repeatedly turned to the person of Augustus to provide their touchstone of authority [5]. Both of these terms appeal to foundational stories and origins as authenticating material. How this can be seen to work will emerge during the course of this argument.

At the beginning of the $5^{\text {th }}$ century, Italia had nominally still been under the rule of Roman Emperors, but they had become puppets of the Goths, who had come to dominate their Italian hosts. Finally the Gothic ruler Odoacer deposed the last Roman Emperor Romulus Augustulus in 476. Theodoric (490-526) was the son of the king of the Goths and grew up as a hostage at the Imperial Byzantine court. When Theodoric himself became King, Emperor Zeno encouraged him to invade Italy as an Imperial ally. Though a German, Theodoric maintained the Roman legal and administrative structures of the state, maintaining that his governors should: "Obey the Roman customs. You are now by God's blessing restored to your ancient freedom; put off the barbarian; clothe yourselves with the morals of the toga; unlearn cruelty, that you may not be unworthy to be our subjects". Since Theodoric was King of Italy with the sanction of the Emperor of the East, Charlemagne considered that the Western Imperial mantle had fallen to Theodoric, who even minted his coins in the name of the Emperor of the East [15, pp. 68-69] (Cassiodorus, Variae, III, 17 [8]). In this sense he restored imperial rule and was greatly admired by Charlemagne who had an equestrian statue of Theodoric taken from the palace at Ravenna and brought back to Aachen.

In his $6^{\text {th }}$-century History of the Franks, Gregory of Tours charts how Roman culture, and in particular Catholic Christianity, was preserved in Gaul by Roman aristocratic and Senatorial families, not least his own, after the final military defeat of the last Roman forces by the Frankish king Clovis. Even as Roman military hegemony crumbled, its culture and mores were greatly admired, to the extent that the barbarian conquerors were assimilated remarkably quickly. Roman culture and Catholic religion were two faces of the same coinage in Gaul, and Clovis himself converted. His greatest pride was that on defeating the Goths and killing Alaric II, the (Eastern) Emperor Anastasius named him Consul. Clovis placed a diadem on his head and wearing a purple tunic, staged an adventus and began to refer to himself as Au- 
gustus [7, p.154]. Romanitas and a Roman title were clearly an important source of enhanced regal authority.

Charlemagne in turn was named Patrician of the Romans, but this time by the Pope who was by the $8^{\text {th }}$ century the ultimate guardian of Romanitas in the City itself. The King was a zealous Catholic and it was, at the very least, an important part of his rhetoric to promote the unification of the Gallican liturgy with Roman practice. Though the practical seriousness of the policy has been questioned (notably by Yishak Hen), the ideological commitment to a royally enacted Romanitas is indisputable.

In terms of building, Charlemagne created his own Lateran in Aachen, described by a laudatory poet as the 'new Rome' in which he calls Charlemagne summus rex and Augustus and describes how he:

Looks out from the lofty citadel of the new Rome

and sees all the kingdoms forged into an empire through his victories.

Our times are transformed into the civilisation of Antiquity.

Golden Rome is reborn and restored anew to the world! [13, p. 273; 5, p. 130]

The general intention is absolutely clear, and the detail of this Romanising project will be revealing for the precise political competition going on beneath this highly civilised veneer. As Charlemagne looked "out from the lofty citadel of the new Rome", what did he see?

Approaching this palace in Aachen on the main axis, he saw the visitor come first to the central gatehouse, or porta. To the left was a covered walkway to the aula regia, a large apsidal audience hall with a throne in the western apse, the walls of which are still extant to a height of a couple of metres above ground, and at the eastern end of the hall still stands the Granusturm which recent archaeological analysis indicates was a complex of rooms and stairs housing the treasury or royal apartments. To the right from the porta was another covered walkway to the Basilica of the Mother of God where the king had access by a winding stair to gallery level and his great ceremonial throne.

In his Life of Charlemagne, Einhard wrote that:

This king, who showed himself so great in extending his empire and subduing foreign nations, ... also undertook very many works calculated to adorn and benefit his kingdom and brought several of them to completion. Among these, the most deserving of mention are the basilica of the Holy Mother of God at Aachen, built with wonderful skill, and a bridge over the Rhine at Mainz five hundred paces long [6, p. 30].

This is an interesting juxtaposition of the dual strategy underpinning the royal power. The western approach to the Basilica was through an atrium with a central bronze pinecone fountain, strongly reminiscent of the atrium of Old St. Peter's in Rome. This arrangement was perhaps as early as Charlemagne or the Romanising project was continued by his successors into Ottonian times. A second fountain still in the Cathedral Treasury is in the form of a bronze she-wolf, identified as second-century AD Hellenistic, like the Roman she-wolf in the Lateran. There is no direct proof it was in Aachen before 1414, but at the very least it recognises, reinforces and extends the Carolingian projection of Romanitas [10, pp. 12-13]. The facade is dominated by a great conch with a massive tribune at gallery level proclaiming the position of the throne above the great west doors which were cast in bronze in the local 
foundry around 800 . These magnificent doors have lions-head knockers recalling those on the Holy Sepulchre. This impressive western facade constitutes a proto-westwork and indicates a royal symbolism in its origin.

On passing through the great westwork, you are in a thrilling three-storey tall octagon modelled on the Byzantine Imperial church of San Vitale in Ravenna and more distantly on the Imperial church of SS Sergius and Bacchus in Constantinople. Such references to eastern Imperial 'Romanitas' made the Byzantines nervous and, as Einhard says,

after [Charlemagne] had taken up the name of emperor they suspected that he might want to seize their empire, so he established such a firm treaty with them that no source of trouble might remain between them. For the power of the Franks was always suspect to the Romans and the Greeks; as the Greek proverb says: "Have a Frank as a friend, not as a neighbour" [6, p. 30].

The octagon is topped by a segmented dome now with a golden mosaic showing Christ in Majesty. Whether or not it was originally in mosaic, we know that the imagery in Charlemagne's day was the same, and it has been argued that a manuscript provided the model (12 Zurich Central Library, including Alcuin, C80 f 83r). Thomas Noble in his book (2009) cites a range of support for the argument that the later imagery of the cupola reproduces the original $[10$, p. 418, n. 189]. At Gallery level, each bay of the octagon opens in a large arch with magnificent paired marble columns. Generally speaking, those in the arches in the cardinal directions are ancient and, before they were stripped out by Napoleon and taken to the Louvre, these columns, many of the capitals, and some of the marble paving beneath the throne, were originally the spolia Charlemagne brought back from Rome and Ravenna, as noted by Einhard:

With great piety and devotion he practised the Christian religion in which he had been reared from infancy. For this reason he constructed a church of great beauty at Aachen and adorned it with gold and silver and lamps, and with railings and portals made of bronze. Since he could not produce columns and marble from anywhere else he took the trouble to have them brought from Rome and Ravenna [6, p. 36].

Most, but not all, of these columns were returned, some to their place in the gallery, some are in the Cathedral Treasury. In bringing the columns for his palace chapel from Ravenna, Charlemagne continued a policy of Theodoric, who wrote to his officials: "We wish to build new edifices without despoiling the old. But we are informed that in your municipality there are blocks of masonry and columns formerly belonging to some building now lying absolutely useless and unhonoured. If it be so, send these slabs of marble and columns by all means to Ravenna, that they may be again made beautiful and take their place in a building there." Theodoric used spolia not in his churches, nor in his mausoleum, but in his palace as an image of his government: "Much do we delight in seeing the greatness of our Kingdom imaged forth in the splendour of our palace". "Thus do the ambassadors of foreign nations admire our power, for at first sight one naturally believes that as is the house so is the inhabitant". For Charlemagne, as for Theodoric, the qualities of material, antiquity, and provenance, all reflected on the government, character and power of the ruler (Cassiodorus, Variae, III, 9 [8])1.

\footnotetext{
On spolia see also Beat Brenk, "Spolia from Constantine to Charlemagne: Aesthetics versus Ideology" [2, pp. 103-109], especially pp. 107-108 where he discusses 'Theodoric' and the 'Nova Gloria Vetustatis' through Cassiodorus' Variae.
} 
It is tempting to interpret all this as evidence of Charlemagne's aspiration to Imperial status, but from Einhard's possible implication that if Charlemagne could have obtained marble more conveniently elsewhere he would, then the argument can be made that the marble was obtained for purely aesthetic reasons which after all were foremost for Theodoric. That argument has indeed been made by Thomas Weigel and Günther Binding [9, p. 197]. There is no denying that a remarkable aesthetic has been produced in Charlemagne's basilica, but there is mounting material evidence of Charlemagne's conscious projection of Romanitas, whether or not it included Imperial aspirations, so it is strange to think that this specially selected material with its broadly, but impeccably, Roman credentials, should be selected for its physical beauty alone.

The paved "carpet" beneath the throne itself must also be spolia since it includes red and green porphyry and grey Egyptian granite. The throne in the gallery emphasises the religious side of Charlemagne's kingship and with its six steps is modelled on the throne of Solomon as described in the First Book of Kings (10.19), but there has clearly not been any attempt to recreate other easily reproduced decorative aspects of the biblical description. Considering the opulence and refinement of the exotic marble columns, and the capitals (some ancient and some very convincingly copied by Carolingian masons), the throne by comparison looks knocked together with crudely shaped stone slabs. The shape of the steps reveals that they were cut from a single column which has graffiti with crosses. The side-panels, bound with simple bronze brackets, also have ancient graffiti with crosses, calvaries and even a board game. This object did not conform to an aesthetic; it was crudely shaped with a minimum of intervention, and its materials were used because of some deeper intrinsic value. Beneath the back of the throne is a cupboard and part of the structure is wooden, dated by dendrochronology to 800 . Small nails and holes in the wood of the base have been identified as fitting precisely the base of the purse reliquary of St. Stephen, Protomartyr, now in Vienna. ${ }^{2}$ With so much emphasis on Romanitas and Charlemagne's stated ideal of RESTORATIO IMPERII ROMANI, the question arises why this particular material, form and reliquary for the throne?

Turning first to the form and material - in 799 a monk of Jerusalem had arrived with blessings and relics of the Holy Sepulchre from the Patriarch in Jerusalem. The nature of the grafitti and analysis of the red-veined stone of the steps and the panels make it extremely likely that these stones are the very relics from the Holy Sepulchre [12], too sacred to be worked further, other than to be shaped in the most basic way. Here auctoritas, authority, is established for Charlemagne's rule by appeal to the Old Testament model, in much the same way as in the eastern Empire, where the throne room, or Chrysotriclenos, was also an octagonal space with a Christ in Majesty above. With the Aachen throne, there is also an appeal to the foundational story of Christianity with stone taken from the very rock of Calvary itself where the Saviour wrought salvation.

And what might explain the choice of reliquary for the Aachen throne? Charlemagne had been anointed King and was crowned Emperor on Christmas Day 800 in St. Peter's in Rome by the pope and it might seem appropriate to have a relic associated with St. Peter in the

2 Purse reliquary of St. Stephen, Reims?, in 2000 dated to 800 [12, p. 188], Kunsthistorisches Museum, Vienna, Schatzkammer (SK XIII 26), illustrated in [1, p. 129]. 
throne. At the ceremony, Einhard writes, "He received the title of Emperor and Augustus. At first he disliked this so much that he said that he would not have entered the church that day, even though it was a great feast day, if he had known in advance of the pope's plan" [6, p.38]. It seems almost inconceivable that he should have objected to the crowning or the titles, in the light of all else, so was there something further within the pope's plan to which he so strongly objected? In the Annales Laurehamenses (which admittedly has been variously assessed as a witness) is the claim that on 23 March 800, when Pope Leo III took the oath of compurgation, denying any guilt for crimes that had led to the plot to maim him and even depose him, the council went on to discuss the restoration of the nomen imperiatoris which was pronounced to be vacant in Constantinople because it had been usurped by a woman, Irene. Charlemagne was not elected by the assembly but is said to have been encouraged to take the imperial title. That same day monks arrived from the Patriarch with the keys of the Holy Sepulchre and a standard. The coronation and consecration has been reconstructed. Now the term consecration was hitherto always of a bishop, with the implication of a sacred order being bestowed. The crown was placed on his head by the pope, and according to both the Royal Annals and the Liber Pontificalis the crowd three times shouted the acclamation "Long life and victory to Charles Augustus, crowned by God, great and peaceful Emperor of the Romans". To be named Augustus was surely the epitome of Romanitas and hardly to be regretted, but in the east, significantly, the acclamations by the Senate, the army, and the people, elect the emperor as chosen by God. In the coronation of Charlemagne, he received the crown at the hands of the pope, and in the acclamations all the people recognised the status received at his hands. Charlemagne had good cause to be angry with the situation since Leo had cleverly subordinated the Imperial power to the Church by reversing the order of the eastern tradition ${ }^{3}$.

The implication of the ceremonial had to be contradicted in the physical reality of the throne. The throne itself was a relic, and the reliquary within its base antedated the Conversion of St. Paul, never mind the deaths of Peter and Paul. True, Peter had already made his confession and was called the Rock, but Stephen was the first to receive the martyr's crown, thus sidelining the Pope as the successor of Peter. The position of the throne in the gallery elevated on steps gave a view of the altars of the Virgin and of St. Peter below and the altar of the Saviour directly opposite in the gallery. Directly above the altar of the Saviour and facing the throne was the apocalyptic image of Christ enthroned, surrounded by the symbols of the Evangelists and offered the crowns of the twenty four elders. The crowns belong to Christ, and it is only a small theological (and political) step to conceive of the imperial crown itself as received directly from Christ, as shown in the painting of the crowning of Otto III in the Treasury of the cathedral. This theological side-lining of the pope became a recurrent theme in the politics of empire.

The iconography of the basilica of the Holy Mother of God "corrects" the implication of the papal ceremonial by showing that Charlemagne occupied the throne by Divine Right, but like his crown, his throne would be surrendered when Christ came again to judge the living and the dead. That time was constantly before the eyes of the Emperor in the decoration of the dome. This was the vision granted to Stephen the Protomartyr, whose relic of bloodstained 
earth was kept within the throne (Acts 7.55-56). It may only have been earth mixed with blood, but it was kept in a purse reliquary studded with jewels and mounted in gold. The rarest, most beautiful and costly gems yielded by the earth were mere decoration for the earth and blood within, that bore witness to the "Son of man standing on the right hand of God". When Christ came again in power, he would occupy the throne in Judgement. Meanwhile Charlemagne was "King by the grace of God" and occupied the throne as "vicar of Christ", as he was called in the earliest literary "Mirror of the Ruler" (Fürstenspiegel). This throne was an intermediary place between earth and heaven. When approaching the palace chapel, it was important to mark with the great conch the significance of the place of the throne in the gallery, making a great reliquary of the basilica itself as a protective chamber for these relics. Here sat Charlemagne on a throne made of stone taken from the Holy Sepulchre, the centre of the world. The image would not be lost on the ambassadors from the Emperor in Constantinople where the Emperor was enthroned on a porphyry disc, embodying the centre of the world [14, p. 50 for reference to the Fürstenspiegel by Maragdus; 12, p. 189 for the throne and its placing]. The juxtaposition of the two thrones, of Charlemagne and of Christ, in the basilica was a theological parallel of the east Roman of the earthly emperor and his court being an exact reflection of the Heavenly Emperor and all the saints of heaven, just as Eusebius had portrayed the rule of Constantine.

In Charlemagne's Palace of Ingelheim, Ermold records that the great hall contained a series of portraits of historical rulers. There, Augustus, Constantine and Theodosius provide the types for Charles Martel, Pepin, and Charlemagne. Ermold commented that "the Franks and their wondrous deeds continue the acts of the Caesars" [3, lines 2068-2165, line 2150-2151, p. 164]. Like Constantine, Charlemagne was founding a Roma Nova as his contemporaries said. These spolia, or recovered materials, constitute the building that is to be seen today. Interestingly, if the bronze wolf and pinecone are later additions, as are certainly the elaborate $19^{\text {th }}$ - and $20^{\text {th }}$-century marble panelling and the mosaic of the drum of the dome, then successive generations have very consciously intensified the claim to Romanitas, and the messages of Roma Nova, to suit their own political agendas.

Title. Building, Enacting and Embodying Romanitas: the Throne of Charlemagne.

Author. Allan George Doig - FSA, Ph. D. Fellow, Tutor for Graduates and Chaplain, Lady Margaret Hall, University of Oxford; The Priory, Hudson Street, Oxon OX15 0SW Deddington, United Kingdom. chaplain@lmh.ox.ac.uk

Abstract. This paper will explore the development of aspects of the ideological underpinning of Charlemagne's Renovatio Romani Imperii. The object under inspection will be Charlemagne's throne in the Basilica at Aachen, and attention will extend to the origin of its materials, its artistic, architectural and ceremonial context, and what it has to tell us about the person and the office of the King-Emperor. Romanitas, in this sense, is a set of ideals projected backwards onto the Christian Roman Empire and its remnants. This vision of Roman identity was made visible in cultural manifestations from daily rituals to art and architecture. Elements of all these had survived the gradual collapse of Roman institutions in the Western Empire. The narrative of the founding of the Christian Empire provided by Eusebius, was explicitly emulated and continued by Gregory of Tours in his History of the Franks, in which he records the elements of the Roman legacy that survived in Merovingian Gaul to the end of the $6^{\text {th }}$ century. With Merovingian royal power exhausted, the Pippinids took the inheritance of these fragments in combination with newly acquired fragments, cultural spolia you might say, and combined them within ecclesiastical and intellectual disciplines from "Rome" itself, to create a renewed Empire in bricolage. The throne will show how this reconstituted romanitas was convincing enough to be mocked (defensively), yet grudgingly admired, and finally recognised by the Emperor in the other "New Rome".

Keywords: the Throne of Charlemagne; Basilica at Aachen; Romanitas; Merovings; Pippinids; Romans; Theodoric.

Название статьи. Трон Карла Великого в Аахене: римская идея и ее воплощение. 
Сведения об авторе. Доиг Аллан Джордж - Ph. D., научный сотрудник, профессор и капеллан, Леди Маргарет Холл, Оксфордский университет. The Priory, Hudson Street, Deddington, Oxon OX15 0SW, Великобритания. сhарlain@lmh.ox.ac.uk

Аннотация. В статье рассматриваются различные аспекты развития идеологической подоплеки каролингского девиза Renovatio Romani Imperii, призывавшего к возрождению Римской империи. В центре внимания автора трон Карла Великого в базилике Аахена - помимо вопроса о происхождении составляющих его материалов анализируется художественный, архитектурный и обрядовый контекст, проливающий свет на личность короляимператора и особенности его правления. Понятие Romanitas в данном случае - это совокупность идеалов, экстраполированных на Позднюю Римскую империю и то, что от нее сохранилось. Самоидентификация с римской имперской идеей разными способами визуально воплощалась как в повседневных ритуалах, так и в изобразительном искусстве и архитектуре. Отдельные элементы целостной концепции, пережив постепенный распад общественных институтов Западной Римской империи, сохранились и в Средние века. Сочинение Евсевия Кесарийского об основании «христианской империи» было решительно поддержано Григорием Турским, а идеи получили развитие в его «Истории франков», где описаны те особенности римского наследия, которые продолжились в меровингской Галлии вплоть до конца VI в. Когда власть династии Меровингов была исчерпана, кое-что из этого наследия усвоили Пипиниды и, соединив его с вновь открытыми фрагментами, так сказать, культурной сполией, а также собственно "римскими» духовными и интеллектуальными принципами, из этих «подручных средств» создали эклектичный концепт обновленной империи. На примере трона в Аахене показано, как возрожденная римская идея, поначалу вызывавшая сомнения и вялое восхищение, в конечном счете была признана императором как идея еще одного «Нового Рима».

Ключевые слова: трон Карла Великого; базилика в Аахене; Меровинги; Пипиниды; римляне; Теодорих.

\section{References}

1. Bagnoli M. The Stuff of Heaven: Materials and Craftsmanship in Medieval Reliquaries. Treasures of Heaven: Saints Relics and Devotion in Medieval Europe. London, British Museum Publ., 2011, pp. 137-147.

2. Brenk B. Spolia from Constantine to Charlemagne: Aesthetics versus Ideology. Dumbarton Oaks Papers, 1987, vol. 41, pp. 103-109.

3. Faral E. (ed.). Ermold, In honorem Hlodowici christianissimi Caesaris Augusti, Ermold le Noir: Poème au roi Louis le Pieux suivi de Epîtres au roi Pépin. Paris, Les Belles Lettres Publ., 1964, XXXVI+267 p. (in French).

4. $\quad$ Folz R. The Coronation of Charlemagne, 25 December 800. London, Routledge \& K. Paul. Publ., 1974. 266 p.

5. Furedi F. Augustus: a role model for authority through the ages. Authority: A Sociological History. Cambridge, Cambridge University Press, 2013, pp. 70-94.

6. Ganz D. (transl.). Einhard and Notker the Stammerer: Two Lives of Charlemagne. London, Penguin Publ., 2008. $160 \mathrm{p}$.

7. Gregory of Tours. The History of the Franks, L. Thorpe (transl.). Harmondsworth, Penguin Classics Publ., 1974. 720 p.

8. Hodgkin T. (ed.). Cassiodorus. The Letters of Cassiodorus, being a Condensed Translation of the Variae Epistolae of Magnus Aurelius Casiodorus, Senator. Oxford, Henry Frowde Publ., 1886.

9. Kinney D. The Discourse of Columns. Rome across Time and Space: Cultural Transmission and the Exchange of Ideas, c. 500-1400. Cambridge, Cambridge University Press, 2011, pp. 182-199.

10. Lepie H.; Minkenberg G. Der Domschatz zu Aachen. Museen und Schatzkammern in Europa. Regensburg, Schnell \& Steiner Publ., 2010. 128 p. (in German).

11. Noble T. Images, Iconoclasm and the Carolingians. Philadelphia, University of Pennsylvania Press Publ., 2009. $488 \mathrm{p}$.

12. Schütte S. Forschungen zum Aachener Thron Dombaumeistertagung 2009: Europäische Vereinigung der Dombaumeister, Münsterbaumeister und Hüttenmeister. Aachen, Dombauleitung Publ., 2009, pp. 177-190 (in German).

13. Smith M. H. J. Europe after Rome: a New Cultural History, 500-1000. Oxford, Oxford University Press Publ., 2005. $398 \mathrm{p}$.

14. Ullmann W. Ecclesiology and Carolingian Rulership. The Carolingian Renaissance and the Idea of Kingship: the Birkbeck Lectures, 1968-69. London, Methuen Publ., 1969, pp. 43-70.

15. Ward-Perkins B. The Fall of Rome and the End of Civilization. Oxford, Oxford University Press Publ., 2005. 256 p. 